\title{
Is Feminist Theory Anti-Feminist? (reprise)
}

\section{Valerie Raoul}

In response to the call for papers for this edition of Tessera I went back and re-read the first issue (Room of One's Own, 8:4, 1984), which was largely inspired by the Vancouver "Women and Words" conference of 1983. As I compared the points of view expressed, by Lorraine Weir and Andrea Lebowitz in particular, I asked myself to what extent the situation has changed since then.

The two articles to which I refer (Lebowitz's "Is Feminist Literary Criticism Becoming Anti-Feminist?" and Weir's "Wholeness, Harmony, Radiance and Women's Writing") present fundamentally opposed views on the function and value of literary theory, and of feminist theory in particular. Lebowitz protests against the elitism and esotericism of post-structuralist theory, seeing the function of theory and criticism as the transmission to students of a body of knowledge and critical thought, which must be communicable in a common idiom. She also objects to the homage paid by deconstructionists, including women, to dominant male figures (Derrida and Lacan). According to her standpoint, feminist theory abandons its original (political) goals when life and theory diverge, when women who are militant/radical feminists can no longer relate to what theorists are saying in terms of precise goals. Women who participate in the male-dominated field of theory are sold-out academics adopting an alien perspective for the benefit of their careers (the Margaret Thatchers of Academe?).

Weir, on the contrary, claims that theory has never been so accessible or relevant to women as it is under the auspices of Derrida, Foucault et al. "Theorists. . . who seek to deconstruct the phallologocentrism - the patriarchal control of structures of language and definitions of meaning - of the Western humanist tradition are our allies." (22). This judgement is certainly closer to the French view that social and political change as well as psychological re-vision are inextricable from ideological/philosophical shifts. Post-modernism is seen by left-wing theorists such as Toril Moi to be politically subversive in its attempt to displace the subject and valorize the (feminine/ different) Other. For the first time, in theory and in critical practice, it is an advantage to be a woman, as one already has a dual perspective. 
Such bi-focalism is related to the use of "feminine" in French theory to designate a standpoint and value-system opposed to the dominant phallic/patriarchal ones, whether they emanate from male or female exponents.

This standpoint raises another thorny issue which has not gone away: whether men can adopt a "feminine" viewpoint and contribute to feminist theory and, conversely, whether feminist theory is relevant to women only. Several recent works of theory move away from separatism towards convergence. Irigaray's Ethique de la différence sexuelle, Elisabeth Badinter's L'Un est l'Autre, and Marilyn French's Beyond Power, a history of the relations between the sexes, all envisage a movement by men towards the feminine position as the only further progress possible, once women have moved as far towards the masculine one as they deem compatible with retaining their "femininity."

Whether "femininity" is in fact definable/desirable/retainable/ escapable remains the central issue in feminist theory. If I saw an article entitled "Is Feminist Theory Becoming Anti-Feminist?" today, I would expect it to be dealing with a different set of problems. The "anti-feminism" in question would not be the imitation of the masculine mode, but an acceptance of traditional male-binary definitions of what is "feminine." These are re-affirmed by elements such as the emphasis on "writing the female body;" the prevalence of "feminine" imagery (weaving, spinning, fluids); the (positive) equation of femininity with madness; the increasing mystical utopianism of certain feminist theorists; the incursion of religious imagery and concepts in the discourse on women (I don't mean "Real Women"); the reaffirmation of the "eternal feminine" in various guises.

We need women engaged in literary theory and competent in its language to be aware of new developments and to deconstruct the discourse of feminism itself. Many students are eager to take up that challenge. It is pragmatically as important to have women philosophers as it is to have women engineers. There is a danger of reviving the old dichotomy between living and writing/thinking, as a choice between real/committed/political/radical feminism and ivory-tower theory. The two activities are in fact inseparable, as is illustrated by so many contemporary writers. The erosion of frontiers between "creative" writing and theory as theory evolves from the play of signifiers, and poetic language calls reference into question is a reflection of the tendency to demolish masculine/feminine oppositions such as reason/ imagination. 
This position is open to the accusation of revisionism and may be perceived as a hangover from humanism. Yet many feminists, even "radical" ones, are in sympathy with other movements concerned with the oppression of men as well as women, and adhere to the basic tenets of humanism, whether it be liberal/socialist/Marxist. They are looking for change, but not sure if subversion from within the system is more or less effective than withdrawal from it (if that were possible).

Feminist theorists are attempting to escape from binary oppositions, yet these abound as one compares the premises of different standpoints and are even evident in the work of single writers, from Simone de Beauvoir to Mary Daly and Luce Irigaray. Recognition and discussion of the plurality/fragmentation of feminism(s) and its/their polyvalent projects is essential at this point. Recent works by Elizabeth Wilson (Hidden Agendas) and Dale Spender (For the Record) are useful recapitulations of some of the central issues. The following list of apparent contradictions (which emerged from teaching a course on French women writers at the University of British Columbia) may also contribute to continuing the debate - the search for workable syntheses/the spinning of inspiring spirals (up/down, in/out, bigger/ smaller?).

An ad boc and incomplete checklist (dialogue with my Other/self)

1) If female students don't understand feminist theory, it is the fault of the theory/the theorists/the teacher.

It is the fault of the student's phallocratic/stereotypically feminine education.

2) French theory is what American theorists need to tune into. Americans cannot assimilate French theory without reductionism/ falsification.

3) the aim of feminist theory is a revolutionary "parler féminin"/ "écriture-femme."

The existing examples frequently seem to be either modelled on word-play made fashionable by men, or to represent a (welcome/ regrettable) return to traditional "feminine" lyricism/"bavardage."

4) Women can express their unique (but common) view-point, which is new (but has always been there) by the use of imagery based on the female body.

This is predictable and a reversal of/parallel to previous male phallic imagery. It makes a difference if the body is/is not hetero-sexual or that of a mother.

5) "God" can be overthrown and replaced by a multiple Goddess without establishing a new (old) religion. 
We don't need Gods or Goddesses. Women are not necessarily, innately mystical.

6) Women's identity is inseparable from their relationship to their mothers and perception of themselves as actual or potential mothers.

Women can be autonomous only if they escape from motherhood.

7) The only hope is to focus on women alone, to be homodirected. Loving men is necessarily ultimately self destructive.

What about our sons? What about the men we love in spite of (because of?) their being men?

8) "Feminine" is a construct with little to do with biological femaleness (eg. Genêt).

This is a pretext for men to intrude in women's issues/realm.

9) Feminism is concerned with showing up traditional sex-role stereotyping as false, and abolishing it.

Feminism is concerned with revalorizing what was previously pejoratively dismissed as feminine. Women must choose the feminine model over the masculine one.

10) Spinning, weaving etc. are inspiring images for feminine creative writing/thinking.

These images are irrelevant (even insulting or comical) to the majority of women, still engaged in the modern equivalent of spinning and weaving.

11) There are many feminisms.

There is only one true feminism.

12) Feminism is a humanism (as was existentialism).

It is radically opposed to humanism.

13) These statements are all contradictory.

They are all "true". We are all different, but we are all women (except the men among us?). 